\title{
Prescribing Providers Estimate Patients' Adherence to Hypertension and Type 2 Diabetes Medications from Patients' Medication-Taking Routines: an Observational Study
}

\author{
L. Alison Phillips, $P h D^{7}$ and Elise A. G. Duwe, $M D, P h D^{1,2,3}$ \\ 'Department of Psychology, lowa State University, Ames, IA, USA; '²epartment of World Languages and Cultures, lowa State University, Ames, IA, \\ USA; ${ }^{3}$ Northeast lowa Family Medicine Education Foundation, Waterloo, IA, USA.
}

KEY WORDS: patient-provider communication; medication adherence; habit; treatment routines; medical encounter.

J Gen Intern Med 34(9):1688-90

DOI: $10.1007 /$ s11606-019-05054-y

(c) Society of General Internal Medicine 2019

\section{INTRODUCTION}

Patient non-adherence to medications functions as a key mediator between medical practice and patient outcomes, occurring in 20-50\% of patients. ${ }^{1}$ One point of intervention is the medical encounter. ${ }^{2}$ However, providers are hesitant to ask about non-adherence, which leads to poor prescribing decisions and missed opportunities for addressing non-adherence. ${ }^{3}$ Direct questions about non-adherence are not ideal, as they elicit "socially desirable" responses and are subject to poor recall. ${ }^{4}$

We explore the potential benefit of asking about patients' medication-taking routines/habits for estimating adherence. This approach may avoid problems associated with direct questions - patients may not be able to accurately reflect on or want to report specific instances of forgetting a pill, but could describe a "typical daily routine." Further, patients' behavioral habit strength (automaticity in taking medication) predicts adherence more strongly than commonly assessed cognitive predictors (e.g., beliefs ${ }^{5}$ ). Therefore, if providers get a sense of the stability of a patient's routine, they may be able to predict that patient's adherence.

We present data from prescribing medical providers, who used real patients' direct reports of non-adherence and descriptions of their medication-taking routines to estimate patients' objective adherence. We hypothesized that providers' adherence estimates based on patients' medication-taking routines would be equally or more accurate than their adherence estimates based on patients' direct reports of non-adherence.

The findings were recently presented as a poster presentation at the annual meeting of the North American Primary Care Research Group (NAPCRG), November 9, 2018.

Published online May 21, 2019

\section{METHODS}

\section{Patient Data}

Patients on oral hypertension or type 2 diabetes medication completed baseline questions, including "On how many days of the last week did you miss a pill?" and "Please describe your daily routine for taking your medication." Patients selfreported medication adherence. ${ }^{6}$ Patients used Medication Event Monitoring Systems (MEMS; Aardex/MWV) for 1 month. MEMS provided dose frequency (percentage of prescribed pills that were taken) and dose timing (percentage of pills taken within a 2-h dosing window).

\section{Provider Data}

Prescribing providers completed a 10-min online survey in which they read the patients' descriptions of their medication routines and reports of missed pills (from the patient data). Providers estimated the patients' adherence in the subsequent month, from 0 to $100 \%$ for each of the routine descriptions and separately for each report of pills missed.

\section{Analysis}

Bivariate correlations were calculated between providers' adherence estimates and patients' MEMS adherence, and between patients' MEMS adherence and self-reported adherence. Fisher's $Z$ test for comparing correlations in dependent samples determined statistical differences between bivariate correlations.

\section{RESULTS}

Final samples included 75 patients with hypertension (average age $=67.90(\mathrm{SD}=12.28), 63 \%$ female, $73 \%$ White $), 81$ patients with type 2 diabetes (average age $=57.77(\mathrm{SD}=10.86)$, $64 \%$ female, $26 \%$ White), and 59 providers (average age $=$ $40.5(\mathrm{SD}=11.1), 69 \%$ female, $73 \%$ White, average years in practice $=11.8(\mathrm{SD}=11.3))$.

All correlations were significant at $p \leq 0.001$ (see Table 1), except for the correlation between the two types of providers' estimates $(r=0.21, p=0.014)$. Table 2 presents examples of 
Table 1 Descriptive Statistics and Bivariate Correlations of Study Variables

\begin{tabular}{|c|c|c|c|c|c|c|c|}
\hline & $\begin{array}{l}\text { Variable } \\
\text { name }\end{array}$ & Range & $\begin{array}{l}\text { Mean } \\
\text { (SD) }\end{array}$ & 1 & 2 & 3 & 4 \\
\hline 1 & $\begin{array}{l}\text { MEMS dose } \\
\text { timing }\end{array}$ & $\begin{array}{l}3.77- \\
100 \%\end{array}$ & $\begin{array}{l}68.82 \% \\
(28.10)\end{array}$ & & & & \\
\hline 2 & $\begin{array}{l}\text { MEMS dose } \\
\text { frequency }\end{array}$ & $\begin{array}{l}41.67- \\
105.77 \%\end{array}$ & $\begin{array}{l}92.49 \% \\
(11.94)\end{array}$ & .68 & & & \\
\hline 3 & $\begin{array}{l}\text { Providers' } \\
\text { adherence } \\
\text { estimate from } \\
\text { patient's stated } \\
\text { routine }\end{array}$ & $\begin{array}{l}30.91- \\
82.50 \%\end{array}$ & $\begin{array}{l}61.91 \% \\
(14.53)\end{array}$ & .48 & .28 & & \\
\hline 4 & $\begin{array}{l}\text { Providers' } \\
\text { adherence } \\
\text { estimate from } \\
\text { patient's direct } \\
\text { non-adherence } \\
\text { report }\end{array}$ & $\begin{array}{l}54.00- \\
79.00 \%\end{array}$ & $\begin{array}{l}75.92 \% \\
(6.50)\end{array}$ & .41 & .47 & .21 & \\
\hline 5 & $\begin{array}{l}\text { Patients' } \\
\text { reported } \\
\text { adherence }\end{array}$ & $1.4-5$ & $\begin{array}{l}4.69 \\
(0.50)\end{array}$ & .36 & .50 & .32 & .54 \\
\hline
\end{tabular}

patients' stated routines with their actual adherence levels and providers' estimates of their adherence based on their routines.

Table 2 Examples of Patients' Medication-Taking Routine Descriptions, Objective Adherence, and Providers' Average Adherence Estimates After Reading the Descriptions

\begin{tabular}{|c|c|c|c|}
\hline $\begin{array}{l}\text { Patient's } \\
\text { medication-taking } \\
\text { routine }\end{array}$ & $\begin{array}{l}\text { Providers' } \\
\text { average } \\
\text { estimate } \\
(\%)\end{array}$ & $\begin{array}{l}\text { Patient's } \\
\text { dose timing } \\
\text { adherence } \\
(\%)\end{array}$ & $\begin{array}{l}\text { Patient's } \\
\text { dose } \\
\text { frequency } \\
\text { adherence } \\
(\%)\end{array}$ \\
\hline $\begin{array}{l}\text { Because I take } \\
\text { prescribed and } \\
\text { supplements } \\
\text { simultaneously, I take } \\
\text { them all after a meal. I } \\
\text { try to take it after } \\
\text { breakfast. If I'm dashing } \\
\text { about, I'll take it at } \\
\text { lunch. }\end{array}$ & 52.86 & 48.57 & 94.29 \\
\hline $\begin{array}{l}\text { Get up between } 3 \text { and } \\
4 \text { am. I try to take it } \\
\text { sometime in the } \\
\text { morning, say } 9 \text { am, but I } \\
\text { have a constantly } \\
\text { fluctuating schedule. I } \\
\text { just try to take it } \\
\text { whenever. }\end{array}$ & 40.00 & 42.42 & 100.00 \\
\hline $\begin{array}{l}\text { Get up, take it very first } \\
\text { thing because must be } \\
\text { time lag between taking } \\
\text { it and eating. Then } \\
\text { shower and shave then } \\
\text { eat. }\end{array}$ & 82.50 & 100.00 & 100.00 \\
\hline $\begin{array}{l}\text { I take my meds while } \\
\text { boiling water for coffee } \\
\text { together with fish oil } \\
\text { tablets }\end{array}$ & 74.62 & 93.10 & 100.00 \\
\hline $\begin{array}{l}\text { Until just recently I used } \\
\text { to put my ...then I } \\
\text { would eat and take my } \\
\text { pill; other days, I get up } \\
\text { later and I try to get } \\
\text { everything done before I } \\
\text { get out the door. } \\
\text { Weekends are a bit } \\
\text { different. }\end{array}$ & 48.46 & 15.15 & 30.30 \\
\hline
\end{tabular}

Providers' estimates from routine descriptions were equally accurate in predicting dose timing $(Z=0.78, p=$ 0.22 ) and significantly less accurate in predicting dose frequency $(Z=-2.01, p=0.02)$, compared to providers' estimates from direct reports. However, the latter result changed when over-adherers were excluded, with the difference between the correlations becoming non-significant $(Z=-1.24, p=0.11)$. Both providers' estimates predicted patients' dose timing equally to patients' own reports of adherence (on the MARS; $Z=1.41, p=0.08$, and 0.69, $p=0.25$, respectively). Providers' adherence estimates based on patients' direct reports were equally predictive of dose frequency as were patients' own reports of adherence $(Z=0.44, p=0.33)$.

\section{DISCUSSION}

Providers may be able to have patients describe their daily routine for taking their medication(s) to estimate the patient's likely adherence, avoiding issues with direct questions. This approach could further allow the provider to address the lack of routine during the encounter. Of interest, and what has not been found in prior research, to our knowledge, is that providers were equally accurate in estimating patients' objective adherence as were patients in reporting their adherence. A conversational approach of asking an open-ended question about the patient's typical medication-taking routine may function better than standardized self-report measures of adherence for predicting adherence.

Future research should test the effect of asking patients these questions in medical encounters. Real medical encounters would allow for follow-up questions regarding a patient's routine or lack thereof, thus the provider may be even better at estimating the patient's adherence than was observed in this study.

Acknowledgments: Dr. Howard Leventhal and Dr. Elaine Leventhal were involved in data collection and study design for the study of patients with hypertension. Dr. Joshua Cohen and Dr. Edith Burns were involved in the data collection and study design for the study of patients with type 2 diabetes.

Corresponding Author: L. Alison Phillips, PhD; Department of Psychology, Iowa State University, Ames, IA, USA (e-mail: alisonp@iastate.edu).

Funding Information Funds for the research came from internal funds, from Iowa State University to the first author. Funds for the study with patients on hypertension medications came from internal funding to the first author and Dr. Elaine Leventhal, from Rutgers University. Funds for the study with patients on type 2 diabetes medication came from the PhRMA Foundation.

\section{Compliance with Ethical Standards:}

Conflict of Interest: The authors declare that they do not have a conflict of interest. 


\section{REFERENCES}

1. DiMatteo R, Giordani PJ, Lepper HS, Croghan TW. Patient adherence and medical treatment outcomes: A meta-analysis. Med Care.2002;40:794-811.

2. Street RL Jr, Makoul G, Arora NK, Epstein RM. How does communication heal? Pathways linking clinician-patient communication to health outcomes. Patient Educ Couns.2009;74:295-301.

3. Murri R, Antinori A, Ammassari A, Nappa S, Orofino G, Abrescia N Mussini C, D'Arminio Monforte A, Wu AW, AdlCoNA Study Group. Physician estimates of adherence and the patient-physician relationship as a setting to improve adherence to antiretroviral therapy. J Acquir Immune Defic Syndr.2002;31:S158-62.
4. Phillips LA, Leventhal EA, Leventhal H. Factors associated with the accuracy of physicians' predictions of patient adherence. Patient Educ Couns.2011;85(3):461-7.

5. Phillips LA, Cohen J, Burns EA, Abrams J, Renninger S. Selfmanagement of chronic illness: The role of 'habit' vs reflective factors in exercise and medication adherence. J Behav Med.2016;39(6):1076-91.

6. Horne R. The medication adherence report scale. 2004. Brighton: University of Brighton.

Publisher's Note Springer Nature remains neutral with regard to jurisdictional claims in published maps and institutional affiliations. 